\section{Reflective Groundcover Improves Fruit Skin Color in 'Honeycrisp' Apples Grown under Protective Netting}

\author{
Giverson Mupambi ${ }^{1}$, Nadia A. Valverdi ${ }^{1}$, \\ Hector Camargo-Alvarez ${ }^{1}$, Michelle Reid ${ }^{1}$, Lee Kalcsits ${ }^{1}$, \\ Tory Schmidt ${ }^{2}$, Felipe Castillo ${ }^{3}$, and Jonathan Toye ${ }^{3}$
}

AdDitional INDEX wORDs. fruit quality, Malus domestica, photosynthetically active radiation, sunburn

SUMMARY. In semiarid apple (Malus domestica) growing regions, high temperatures and excessive solar radiation can increase the risk of sunburn development. Protective netting is increasingly used as a cultural practice under these conditions to mitigate fruit sunburn losses. However, fruit skin color development can be negatively affected under protective nets due to the reduction in light availability. Reflective groundcovers have been previously reported to increase fruit color development, particularly in the inner parts of the tree canopy. Here, we compared two types of reflective groundcover: a woven polyethylene fabric and a film material with a grassed control without reflective material under a protective netting installation that reduced photosynthetically active radiation $(P A R)$ by $17 \%$. The experiment was conducted in a semiarid climate on a 5-year-old 'Cameron Select Honeycrisp' apple orchard near Quincy, WA. Light penetration into the canopy was measured with a $P A R$ sensor. At harvest, fruit quality, yield, and size were assessed. The use of reflective groundcover between the rows significantly increased reflected $P A R$ into the lower canopy. Moreover, reflective groundcovers significantly increased the amount of fruit with greater than $25 \%$ skin red color compared with the control. Reflective ground cover did not affect fruit weight, yield, and fruit number. The use of reflective groundcover under protective netting can increase light penetration into the canopy, thereby improving fruit skin red coloration in apple.

$\mathrm{P}$ rotective netting is increasingly being used by tree fruit growers worldwide to reduce fruit sunburn and protect trees from hail damage (Mditshwa et al., 2019; Mupambi et al., 2018a). Sunburn is a physiological disorder that causes cosmetic damage to the surface of apple (Malus domestica) fruit. Sunburn is caused by overheating of the fruit surface due to

Received for publication 10 Dec. 2020. Accepted for publication 7 July 2021.

Published online 18 August 2021.

${ }^{1}$ Department of Horticulture, Washington State University, Tree Fruit Research, and Extension Center, 1100 N Western Avenue, Wenatchee, WA 98801

${ }^{2}$ Washington Tree Fruit Research Commission, 1719 Springwater Avenue, Wenatchee, WA 98801

${ }^{3}$ Extenday USA Inc, $702 \mathrm{~W}$. Valley Mall Boulevard, Union Gap, WA 98903

Current address for G.M.: UMass Cranberry Station, I State Bog Road East, Wareham, MA 02746

G.M. is the corresponding author. E-mail: gmupambi@umass.edu.

This is an open access article distributed under the CC BY-NC-ND license (https://creativecommons. org/licenses/by-nc-nd/4.0/).

https://doi.org/10.21273/HORTTECH04776-20 excessive solar radiation and high ambient temperatures (Racsko and Schrader, 2012; Wünsche et al., 2004). There are three types of sunburn that develop in apple fruit: sunburn necrosis, sunburn browning, and photooxidative sunburn (Felicetti and Schrader, 2008; Schrader et al., 2001). Fruit with sunburn necrosis is culled in the orchard or sent for processing. Sunburn causes significant fruit losses in productive apple-growing areas worldwide, the majority of which are located in semiarid and arid climates such as Washington State, South Africa, Israel, Chile, and Australia
(Mupambi et al., 2018b). Protective netting is also gaining popularity as a pest control method in apple production (Candian et al., 2020; Chouinard et al., 2019; Mukherjee et al., 2019). In the future, protective netting may play a key role in tree fruit integrated pest management due to its ability to offer protection from some pests and disorders experienced in orchards.

Reflective groundcovers are used to influence the orchard microclimate by increasing light penetration into the inner part of the tree canopy. This results in improved fruit quality directly attributable to the improvement of light availability into the canopy (CorelliGrappadelli, 2003). The deployment of reflective groundcover late in the growing season can improve fruit color in red or partially red apple cultivars (Schmidt, 2010). The deployment of reflective cover 4 weeks before harvest improved fruit color in 'Gala' consistently over three growing seasons in Washington (Schmidt, 2010). Research in Germany has shown that reflective groundcover under protective netting improves orchard light use efficiency, fruit quality, and coloration in 'Gala Mondial' apple (Meinhold et al., 2011).

Protective netting decreases the occurrence of sunburn by reducing both the amount of solar radiation reaching the fruit and the fruit surface temperature. However, light is also required for red color formation in apples, and red color is localized in the areas most exposed to the sun (Siegelman and Hendricks, 1958). Apple fruit from the outer canopy that are exposed to more solar radiation is usually redder compared with shaded fruit in the inner canopy (Jackson and Sharples, 1971). The reduction in solar radiation reaching the fruit surface under protective netting has been reported to adversely affect fruit red color formation in red and bicolored apple cultivars such as Gala, Fuji, and Pinova (Do Amarante 
et al., 2011; Solomakhin and Blanke, 2010). Therefore, the challenge with using protective netting for sunburn reduction in apples is finding the optimal balance between sunburn reduction and fruit color formation. By using the reflective groundcover, sunlight reduction under the nets may be mitigated by reflecting some light back into the tree canopy. Here, the objective of our study was to test whether reflective fabrics improve light penetration in the tree canopy under protective netting and improve fruit color in bicolored 'Honeycrisp' apples in Quincy, WA.

\section{Materials and methods}

Plant Material

AND EXPERIMENTAL SETUP. The experiment was conducted in a commercial 5-year-old 'Cameron Select Honeycrisp' bicolored apple orchard on 'Budagovsky 9' rootstock located near Quincy, WA (lat. $47.22^{\circ} \mathrm{N}$, long. $119.94^{\circ} \mathrm{W}$ ) in 2018 and 2019. The orchard is located in a semiarid climate with an annual average precipitation of $198 \mathrm{~mm}$. Average daily maximum temperatures during the growing season from April to October were 23.5 and $22.5^{\circ} \mathrm{C}$ for 2018 and 2019 , respectively. Historical $P A R$ data obtained from a nearby site in Wenatchee, WA (lat. $47.26^{\circ} \mathrm{N}$, long. $120.20^{\circ} \mathrm{W}$ ) showed that daily average maximum photosynthetic photon flux (PPF) density during the growing season was 1775 and $1772 \mu \mathrm{mol} \cdot \mathrm{m}^{-2} \cdot \mathrm{s}^{-1}$ for 2015 and 2016, respectively (Mupambi et al., $2018 \mathrm{~b}$ ). Trees were spaced $2 \mathrm{ft}$ apart in the row with $12 \mathrm{ft}$ between rows ( 1815 trees/acre) and trained to a V-trellis system. Normal commercial cultural practices of irrigation, bloom, hand thinning, pruning, pest management, and fertilization were followed during the study. The orchard had a microsprinkler system for irrigation. Winter pruning was done to remove excess growth each year. Chemical thinning was done at full bloom, and in the summer, hand pruning was done at $40-\mathrm{mm}$ fruit size.

Before this particular study, protective netting was first deployed on the trial site in May 2015 after full bloom and pollination and retracted every October. During the experiment, netting was deployed in the third week of June 2018 and the middle of May 2019. The netting consisted of $17 \%$ white protective nets installed at a height of $4 \mathrm{~m}$ above the ground and 1 $\mathrm{m}$ above the tree canopy. The protective netting used was a commercially available product made from high-density polyethylene (Extenday, Auckland, New Zealand). Three treatments were established under the protective netting. The treatments comprised two reflective groundcovers laid in between tree rows and a grassed control. The two reflective groundcovers used in the study were a woven polyethylene fabric (Extenday) and a film material (Mylar; DuPont, Wilmington, DE). The woven polyethylene fabric and film material were deployed at $\approx 5$ weeks and $\approx 2$ weeks before harvest, respectively. The reflective groundcovers treatments were $3.0 \mathrm{~m}$ wide, and each treatment replicate was $18 \mathrm{~m}$ long, covering 40 trees. The treatments were arranged in a randomized block design with five replicates. Each treatment plot consisted of four adjacent rows, with the exterior two rows serving as guard rows protecting the two interior rows where all trial data were collected. To measure yield, two trees were selected as sample trees from the inside two rows in each treatment replication. In total, 30 trees were assessed that had normal crop load and tree growth above the top wire.

Light INTENSITY. In 2018, light was measured 1 week before harvest using a PAR sensor (Apogee Instruments, Logan, UT) in each treatment replicate at $1.5 \mathrm{~m}$ above the ground. Measurements were done as spot measurements at solar noon within the tree canopy and in the middle of the drive row. Measurements included incoming $P A R$ (sensor facing up), reflected $P A R$ (sensor facing down), and diffused $P A R$ (sensor at a $45^{\circ}$ angle facing down) (Solomakhin and Blanke, 2007). For the diffuse measurements, the sensor was orientated toward the east. A single measurement was done for each position in a treatment replicate. The within canopy measurements were done next to the trunk. Light measurements were not done in 2019.

Reflected LIGHT QUALITY. Reflected light quality was measured l week before harvest in 2018 using a spectrometer (Lighting Passport; Asensetek, New Taipei City, Taiwan). Measurements were done as spot measurements at solar noon with the sensor facing down at $1.5 \mathrm{~m}$ aboveground. One measurement was done for each treatment. For the reflective groundcover, spot measurements were done on a spot that was clean with no leaf debris. The spectrometer was connected to an android cellphone via Bluetooth during measurements. Graphing of the data collected were done using computer software (Spectrum Genius Standard, Asensetek).

FrUIT YIELD, SIZE DISTRIBUTION, AND QUALITY. Fruit from selected sample trees were harvested in a single pick on 4 Sept. 2018 and 6 Sept. 2019 at commercial maturity. The total number of fruit from each sample tree was counted, and all fruit were then weighed in bulk in the field to obtain average fruit weight. Sixteen fruit were selected randomly from each tree were then transported to the

Table 1. Values of incoming, reflected and diffuse photosynthetically active radiation $(P A R)$ of two reflective groundcovers, compared with a grassed control treatment measured in the middle of the row (midrow) and within the canopy in 'Honeycrisp' apple in 2018.

\begin{tabular}{lccc}
\hline & Incoming $P A R$ & Reflected $P A R$ & Diffuse $P A R$ \\
\cline { 2 - 4 } & \multicolumn{3}{c}{ Mean $\pm \mathrm{SE}\left(\mu \mathrm{mol} \cdot \mathrm{m}^{-2} \cdot \mathrm{s}^{-\mathbf{1}}\right)$} \\
\cline { 2 - 4 } Treatment & $1297 \pm 14.7 \mathrm{a}^{\mathrm{z}}$ & $50 \pm 4.6 \mathrm{c}$ & $61 \pm 7.3 \mathrm{c}$ \\
\hline Control & $1289 \pm 20.9 \mathrm{a}$ & $419 \pm 4.8 \mathrm{~b}$ & $415 \pm 11.4 \mathrm{~b}$ \\
Woven polyethylene fabric & $1307 \pm 17.2 \mathrm{a}$ & $449 \pm 9.7 \mathrm{a}$ & $530 \pm 20.4 \mathrm{a}$ \\
Film material & 0.6593 & $<0.0001$ & $<0.0001$ \\
$P$ value & $65 \pm 3.4 \mathrm{~b}$ & $16 \pm 1.2 \mathrm{c}$ & $22 \pm 2.3 \mathrm{~b}$ \\
\hline & $119 \pm 15.9 \mathrm{a}$ & $148 \pm 6.6 \mathrm{~b}$ & $80 \pm 3.4 \mathrm{a}$ \\
Control & $100 \pm 3.5 \mathrm{ab}$ & $206 \pm 6.3 \mathrm{a}$ & $99 \pm 13.4 \mathrm{a}$ \\
Woven polyethylene fabric & 0.0159 & $<0.0001$ & $<0.0001$ \\
Film material & \multicolumn{4}{c}{ Canopy } \\
$P$ value &
\end{tabular}

${ }^{\mathrm{z}}$ Different letters denote significant differences among treatments within columns. Mean separation determined using a Tukey's test $(\alpha=0.05)$. 

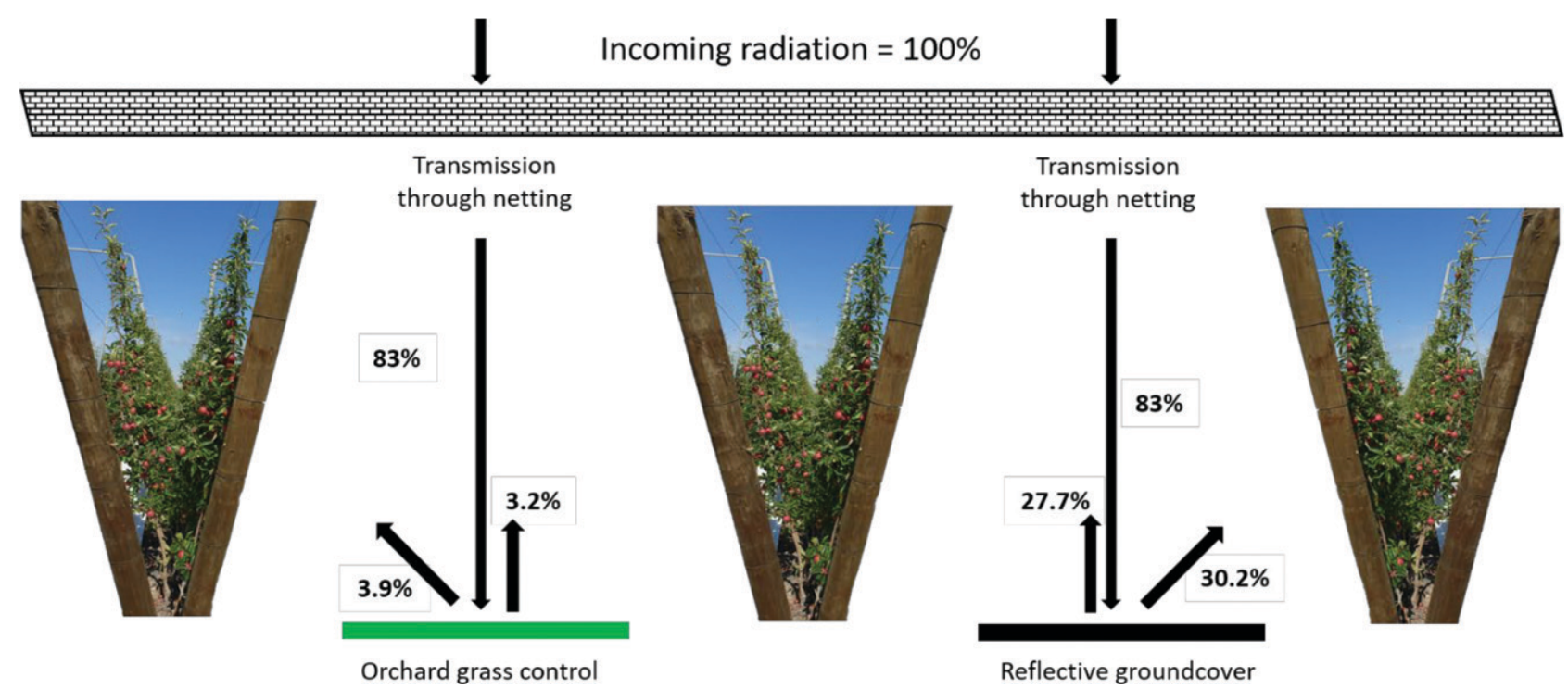

Fig. 1. Conceptual figure showing relative light transmission through protective netting, reflected, and diffuse light from between tree rows under reflective groundcover compared with a grassed control in a 'Honeycrisp' apple orchard. The amount of light transmitted through netting was calculated from measuring incoming solar radiation with and without protective netting at solar noon. The data used in the figure represents both woven polyethylene fabric and film material.

laboratory for fruit quality analysis. Eight of the 16 fruit per tree were stored for 3 months in regular atmosphere storage at $1^{\circ} \mathrm{C}$ and were evaluated for bitter pit incidence after storage. The other eight fruit were immediately analyzed for overall color, background color, starch, soluble solid concentration (SSC), titratable acidity (TA), firmness, and sunburn.

Color classification and background color were evaluated visually according to the Washington State Tree Fruit Research Commission's
(WTFRC) color classification scale and background color scale for 'Honeycrisp' apple. Color classification was based on the coverage of red skin color on the fruit surface where a value of $1=$ $0 \%$ to $25 \%, 2=25 \%$ to $50 \%, 3=50 \%$ to $75 \%$, and $4=75 \%$ to $100 \%$ red color.

\section{Incoming radiation $=100 \%$}

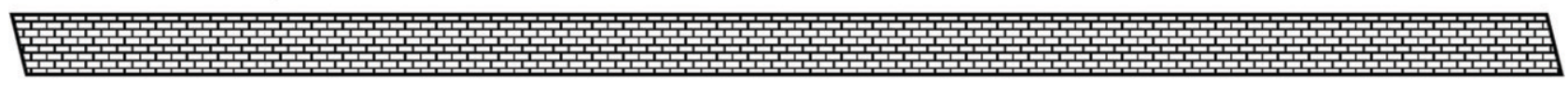

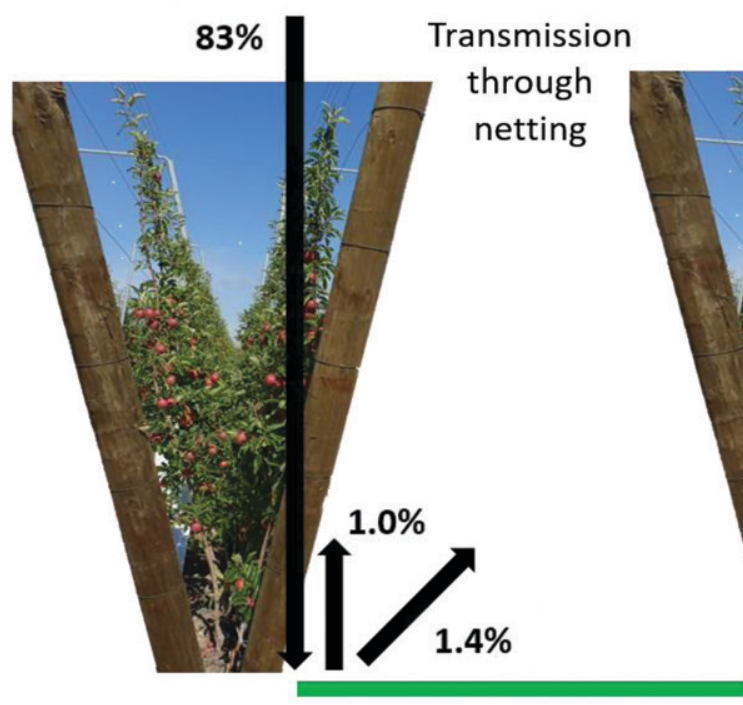

$4.2 \%$

\section{Orchard grass \\ control}

Transmission

through

netting

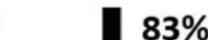

$83 \%$

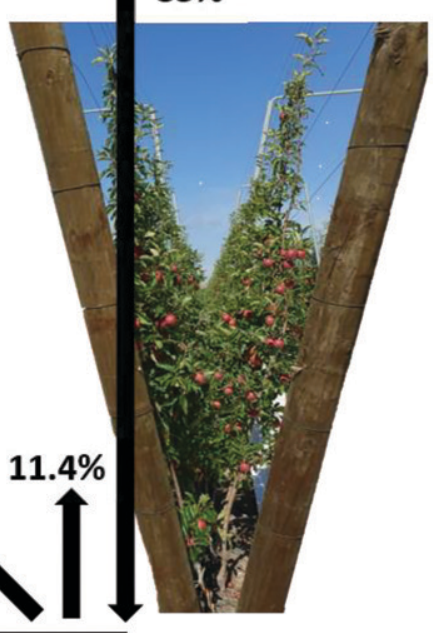

$5.7 \%$

Reflective

$7.0 \%$

groundcover

Fig. 2. Conceptual figure showing relative light transmission through protective netting, reflected, and diffuse light from in the tree canopy under reflective groundcover compared with an orchard grassed control in a 'Honeycrisp' apple orchard. The amount of light transmitted through netting was calculated from measuring incoming solar radiation with and without protective netting at solar noon. The data used in the figure represents both woven polyethylene fabric and film material. 


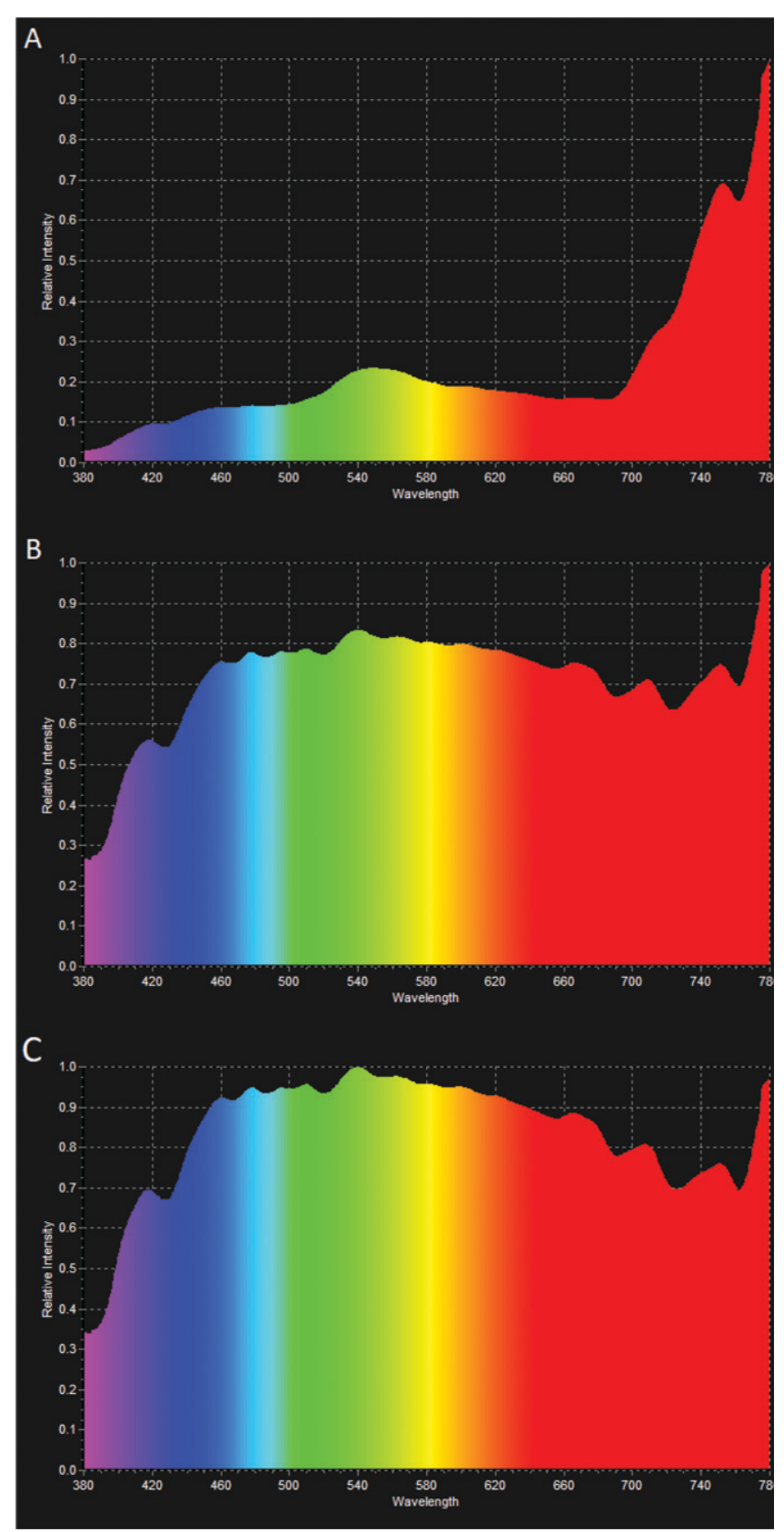

Fig. 3. Reflected light quality measured $1.5 \mathrm{~m}(4.92 \mathrm{ft})$ above the ground from a grassed control (A), woven polyethylene fabric (B), and film material (C) measured using a spectrometer in a 'Honeycrisp' apple orchard grown under protective netting.

Background skin color was also rated on a scale of 1 to 4 based on visual assessment where 1 = green, 2 = greenyellow, 3 = yellow, and $4=$ complete red overcolor. Fruit sunburn was scored using an adjusted 'Gala' sunburn severity scale from Schrader et al. (2003) similar to Kalcsits et al., (2017) for 'Honeycrisp' apple where clean represented no sunburn and Yl to Y3 refer to different stages of sunburn browning. Additionally, color was measured on both sun-exposed side and shade side using a colorimeter (CR-400;
Konica Minolta, Tokyo, Japan), where $\mathrm{L}^{*} \mathrm{a} * \mathrm{~b}$ was measured; L* expresses color from black (0) to white (100), a* from green (negative value) to red (positive value) and b* from blue (negative value) to yellow (positive value). From these parameters, chroma and hue angle were obtained for statistical analysis. Chroma is a measure of color intensity and hue angle is the perceived color where greater values indicate less red and more green color.

Sections of fruit peel were removed both on the sun and shade site at the equatorial region of the fruit for subsequent fruit firmness analysis using a fruit texture analyzer (Güss Manufacturing, Strand, South Africa) with a $10-\mathrm{mm}$ probe. The average of the two measurements per fruit was recorded. Apples were then cut in half on the horizontal axis, and the starch index was evaluated on the bottom (calyx) half of the fruit. Starch was rated 10 min after spraying the fruit flesh with $0.04 \mathrm{M}$ potassium iodide to stain the starch granules in the cortex. The starch was assessed using a scale developed for 'Honeycrisp' apple by WTFRC on a 1 to 6 scale, where 1 indicated maximal starch concentration and 6 indicated no apparent starch retention (Hanrahan, 2012). A small section of fruit $(\approx 1$ $\mathrm{cm}^{3}$ ) was taken from the remaining portion of the top (stem) half of fruit and pressed in a garlic press; two drops of the exuded juice were pipetted onto the measurement surface of a handheld refractometer (3810; Atago, Bellevue, WA) to determine SSC. Another section of the top (stem) half of fruit $(\approx 5$ $\mathrm{cm}^{3}$ ) of the fruit was combined with other sections from the same replicate to form a composite sample for TA and $\mathrm{pH}$ analysis. Juice from the combined fruit samples was extracted using a high-capacity juicer (The Champion Juicer, Lodi, CA). Approximately 50 $\mathrm{mL}$ of juice from each replicate was immediately frozen at $-20^{\circ} \mathrm{C}$. For analysis, juice was removed from the freezer and allowed to thaw at room temperature. A modified titrimetric method was performed using an automated titrator (Metrohm, Herisau, Switzerland). Potassium hydroxide $(0.1 \mathrm{~N})$ was used to establish a $\mathrm{pH}$ of 8.2 as an endpoint. Automated data recording software and controls were performed using Tiamo Software (Metrohm). Acidity data are presented as percent malic acid equivalent.

Statistical analysis. Photosynthetically active radiation data were analyzed using analysis of variance (ANOVA), where significant differences occurred means were separated by the Tukey post hoc test at $95 \%$ confidence level [PROC GLM (SAS version 9.4; SAS Institute, Cary, NC)]. For analysis of yield and fruit quality, data from the two sample trees in each treatment replication were averaged. To evaluate the effect of the protective groundcover on fruit quality, data from both years were pooled and a 
one-way block ANOVA performed including the effect of year as a second blocking variable. Where significant differences occurred means were separated by the Tukey post hoc test at $95 \%$ confidence level. Scale variables from both years were pooled, and frequencies by treatment and category were calculated. Ordinal scale variables such as red skin color, starch, and sunburn were analyzed by the proportional odds model (SAS PROC LOGISTIC), which compares the odds of each treatment of being in lower levels of the dependent variables. Nominal scale variables such as background color and bitter pit were analyzed using the generalized logit function (SAS PROC LOGISTIC), which compares the odds of each treatment of being within a specific category (Elkin, 2012; Lammertyn et al., 2000).

\section{Results}

Photosynthetically active radiation reflected either upwards or into the lower canopy was significantly affected by placing reflective groundcover between the rows (Table 1). Reflected and diffuse light intensity from the film material was significantly higher than in the woven polyethylene fabric and grassed control when measured in the middle row. There were no differences in incoming $P A R$ in the middle of the row. However, when $P A R$ was measured within the tree canopy, incoming $P A R$ was greater with use of reflective groundcover compared with the grassed control. Similar to middle of the row, reflected $P A R$ under the film material was significantly higher compared with woven polyethylene fabric and grassed control within the tree canopy. Diffuse PAR within the tree canopy was significantly higher with use of reflective groundcovers compared with the control. Reflected and diffuse PAR between rows was only between $3 \%$ to $4 \%$ of total incoming $P A R$ in the grassed control plots compared with $27 \%$ to $31 \%$ for reflective groundcover plots (Fig. 1). Within the canopy, reflected and diffuse $P A R$ was between $1 \%$ and $2 \%$ of total incoming $P A R$ in the grassed control plots compared with $5 \%$ to $12 \%$ for reflective groundcover plots (Fig. 2). Reflective groundcover increased light intensity in the 380 - to $740-\mathrm{nm}$ range compared with the control (Fig. 3). The film material increased light intensity in the 420 - to
Table 2. Yield, mean calculated fruit weight, and crop load in 'Honeycrisp' apple grown under protective netting with two different types of reflective groundcovers installed between tree rows compared with a grassed control.

\begin{tabular}{|c|c|c|c|}
\hline \multirow[b]{3}{*}{ Treatment } & Yield $(\mathrm{kg} / \text { tree })^{\mathrm{z}}$ & Fruit wt $(g)^{z}$ & Fruit (no.) \\
\hline & \multicolumn{3}{|c|}{ Mean \pm SE } \\
\hline & \multicolumn{3}{|c|}{2018} \\
\hline Control & $16 \pm 0.8$ & $299 \pm 14.7$ & $53 \pm 4.1$ \\
\hline Woven polyethylene fabric & $16 \pm 0.8$ & $301 \pm 12.6$ & $53 \pm 3.0$ \\
\hline Film material & $17 \pm 0.7$ & $296 \pm 8.7$ & $57 \pm 2.7$ \\
\hline \multirow[t]{2}{*}{$P$ value } & 0.4924 & 0.9614 & 0.6692 \\
\hline & \multicolumn{3}{|c|}{2019} \\
\hline$\overline{\text { Control }}$ & $15 \pm 0.9$ & $245 \pm 12.5$ & $62 \pm 5.1$ \\
\hline Woven polyethylene fabric & $13 \pm 0.9$ & $246 \pm 12.7$ & $54 \pm 4.6$ \\
\hline Film material & $14 \pm 0.8$ & $254 \pm 12.2$ & $57 \pm 4.8$ \\
\hline$P$ value & 0.2914 & 0.8703 & 0.5300 \\
\hline
\end{tabular}

${ }^{\mathrm{z}} \mathrm{lg}=0.0353 \mathrm{oz}, \mathrm{l} \mathrm{kg}=2.2046 \mathrm{lb}$. 700-nm range compared with woven polyethylene fabric (Fig. 3).

Yield (kilograms of fruit per tree), fruit weight, and the number of fruit per tree were no different between treatments for both years (Table 2). Yield was lower in 2019 than 2018 because of transitioning from an "on" year in 2018 to an "off" year in 2019 due to the biennial bearing characteristic of 'Honeycrisp'. Fruit weight was also lower in 2019 compared with 2018. Fruit harvested from trees with the grassed control had a higher probability of lower red color coverage $(0 \%$ to $25 \%)$ compared with fruit from reflective groundcover treatments (Fig. 4). Background color, which indicates chlorophyll degradation during ripening, was affected by the use of woven polyethylene fabric compared with the grassed control; fruit from film material was not significantly different compared with the control (Fig. 5). Fruit harvested from woven polyethylene fabric had a higher probability of complete chlorophyll degradation compared with the control (Fig. 5). Fruit color composition

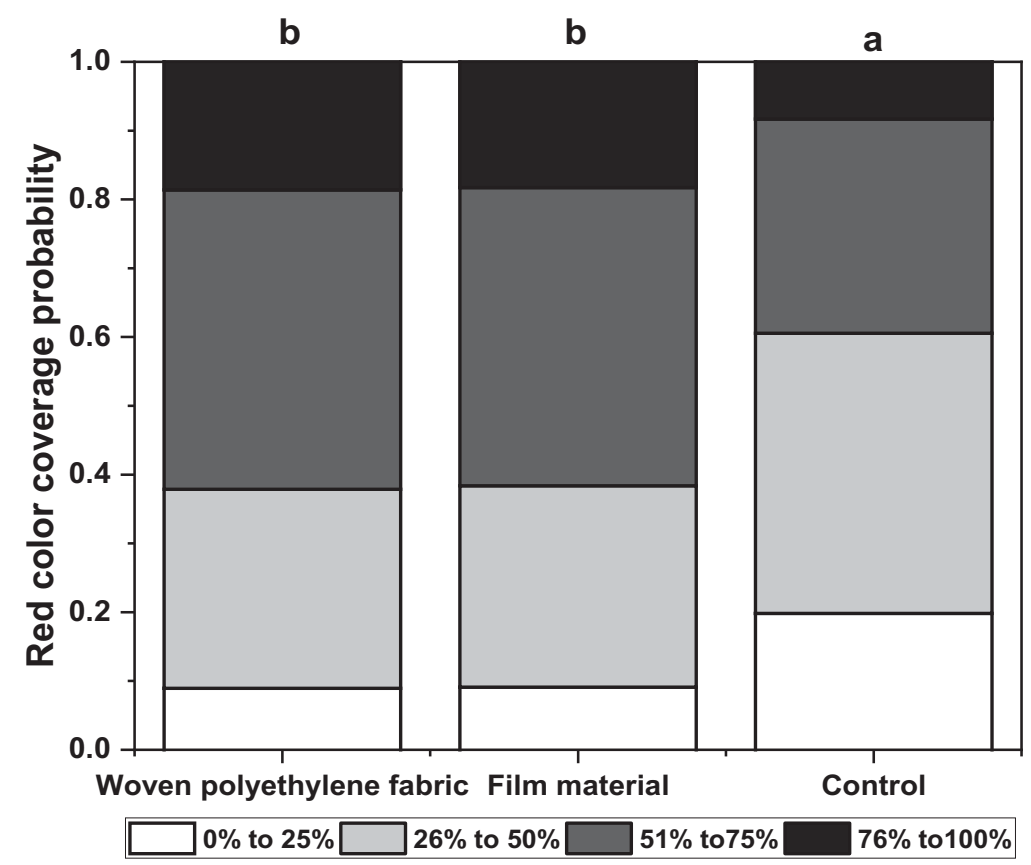

Fig. 4. Probability of red color coverage at harvest for 'Honeycrisp' apple trees grown under protective netting with two types of reflective groundcovers installed between tree rows compared with a grassed control. Different letters denote the probability having lower values in the scale ( $0 \%$ to $25 \%$ coverage), data were analyzed as ordinal categorical variables using the proportional odds model. 


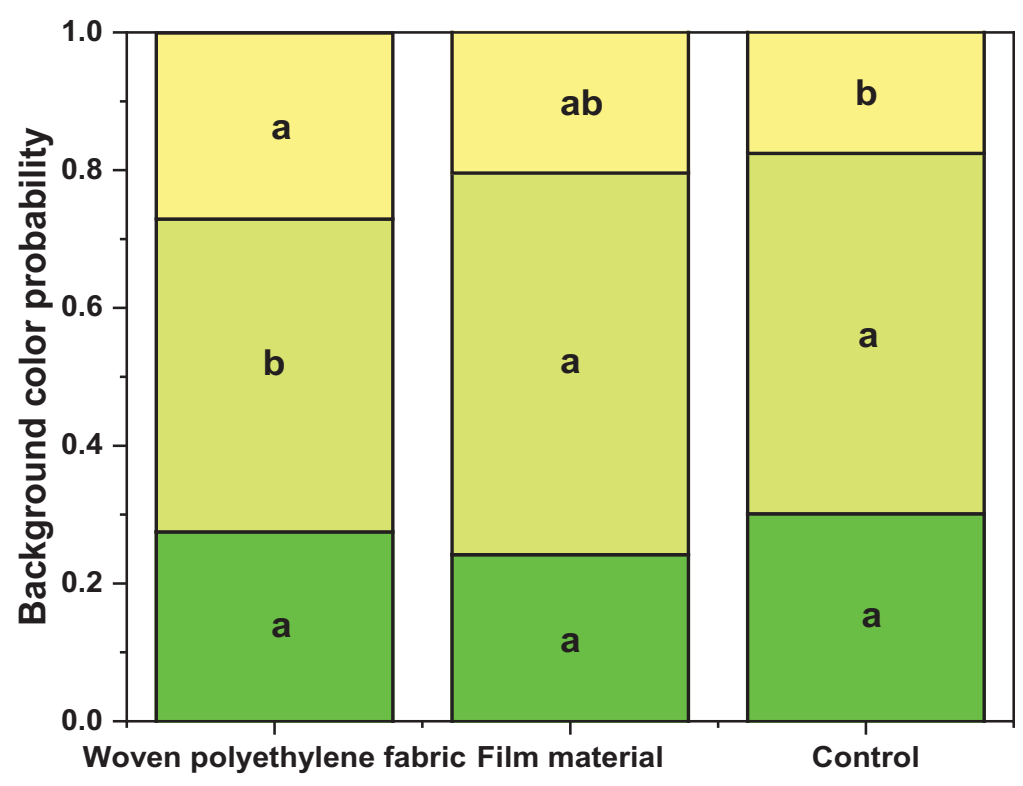

Green $\square$ Green-Yellow

Control

Yellow

Fig. 5. Probability of background color at harvest for 'Honeycrisp' apple trees grown under protective netting with two types of reflective groundcovers installed between tree rows compared with a grassed control. Different letters denote significant differences among treatments within categories; data were analyzed as nominal variables using the generalized logit function.

measured with a colorimeter showed a significant difference between fruit from treatments with reflective groundcover was installed between tree rows and those from the grassed control (Table $3)$. Lightness (L) and hue $\left(\mathrm{h}^{\circ}\right)$ parameters on the shaded part of the fruit from the control treatment were lighter and less red than fruit from both reflective groundcover treatments (Table 3 ). For the sun-exposed part of the fruit, chroma, light, and hue values were more intense, lighter, and less red for fruit from the control treatment compared with reflective groundcovers. There was no effect of reflective groundcovers on fruit firmness, starch, SSC, TA, pH, and bitter pit incidence (data not shown). Sunburn incidence was higher for fruit harvested in the film material treatment compared with woven polyethylene fabric and grassed control (Fig. 6). The film material had significantly less clean fruit compared with the grassed control and woven polyethylene fabric.

\section{Discussion}

The reduction in light penetration into the tree canopy under protective netting has both positive and negative implications for external fruit quality in apple production. Previous studies have shown that sunburn, which negatively affects fruit visual quality, is reduced under protective netting compared with an uncovered control (Do Amarante et al., 2011; Gindaba and Wand, 2005; Iglesias and Alegre, 2006; Kalcsits et al., 2017). On the other hand, red color formation is sometimes negatively affected under protective netting (Iglesias and
Alegre, 2006; Solomakhin and Blanke, 2010). The use of reflective fabrics under protective netting represents a potential solution to the negative effect on fruit color while still reducing sunburn incidence. Results from our study indicated that reflective fabrics increased the amount of diffuse and reflected light in the canopy. The increase in diffuse and reflected light resulted in improved red skin coloration in our study. Red color development in bicolored apple cultivars requires exposure to sunlight (Fouché et al., 2010; Hirst et al., 1990; Siegelman and Hendricks, 1958). Our study showed increased sunburn incidence with film material compared with the woven polyethylene fabric and the grassed control. This can the explained by the higher reflected and diffuse light intensity under film material.

The amount of incoming PAR inside the tree canopy was increased when reflective material was used. This can be partly explained by the reflected and diffuse light bouncing back from the leaf surfaces. Palmer (1977) reported a leaf reflectance of $10 \%$ to $13 \%$ at $550 \mathrm{~nm}$ for 'Golden Delicious' apple trees. The silver, hairy abaxial leaf surfaces have been reported to increase the reflection of light in olive [Olea europaea (Schwabe and Lionakis, 1996)]. To our knowledge, there are no published studies on reflectance properties of adaxial and abaxial leaf surfaces in apple. However, this may explain observed increases in reflected light inside the tree canopy. Similarly, in other crops, Walter-Shea et al. (1991) reported that reflectance and transmittance properties of adaxial and abaxial surfaces differed by as much as $5 \%$ in soybean (Glycine max), whereas there were essentially no differences observed in corn (Zea mays). These changes to inner canopy light conditions could have implications on carbon balance and flower development, especially

Table 3. Lightness, chroma, and hue angle for the sun-exposed and shaded side in 'Honeycrisp' apple fruit at harvest grown under protective netting with two types of reflective groundcovers installed between tree rows compared with a grassed control.

\begin{tabular}{|c|c|c|c|c|c|c|}
\hline \multirow[b]{2}{*}{ Treatment } & \multicolumn{2}{|c|}{ Lightness } & \multicolumn{2}{|c|}{ Chroma } & \multicolumn{2}{|c|}{ Hue angle } \\
\hline & \multicolumn{6}{|c|}{ Mean \pm SE } \\
\hline Control & $58 \pm 0.8 \mathrm{a}^{\mathrm{z}}$ & $83 \pm 0.6 a$ & $38 \pm 0.5 \mathrm{a}$ & $25 \pm 1.2$ & $74 \pm 2.4 \mathrm{a}$ & $66 \pm 2.3 \mathrm{a}$ \\
\hline Woven polyethylene fabric & $55 \pm 0.7 \mathrm{~b}$ & $81 \pm 0.7 b$ & $36 \pm 0.3 b$ & $25 \pm 1.0$ & $65 \pm 2.1 \mathrm{~b}$ & $60 \pm 2.5 \mathrm{~b}$ \\
\hline Film material & $55 \pm 0.6 \mathrm{~b}$ & $82 \pm 0.7 b$ & $36 \pm 0.3 b$ & $26 \pm 1.0$ & $64 \pm 1.9 b$ & $60 \pm 2.5 \mathrm{~b}$ \\
\hline
\end{tabular}

${ }^{\mathrm{z}}$ Different letters denote significant differences among treatments within columns. Mean separation determined using a Tukey's test $(\alpha=0.05)$. 


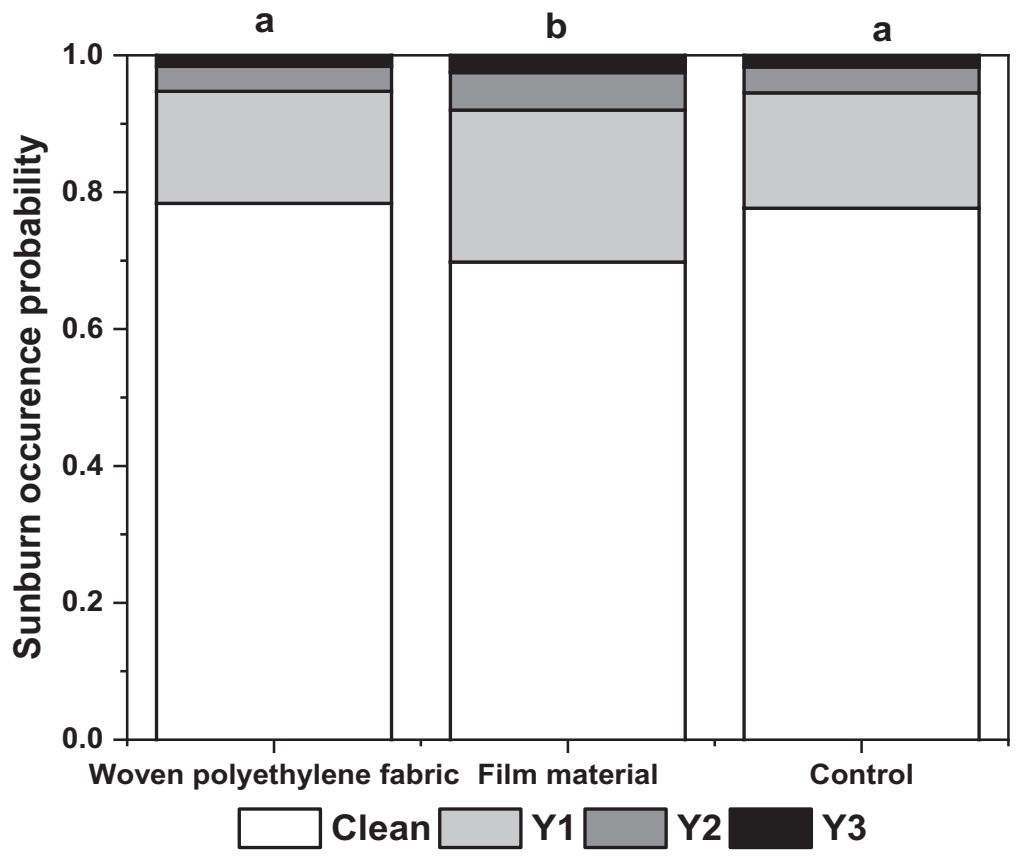

Fig. 6. Probability of sunburn occurrence at harvest in 'Honeycrisp' apple trees grown under protective netting with two types of reflective groundcovers installed between tree rows compared with a grassed control. Clean fruit indicates no sunburn, whereas Y1 to Y3 indicate increasingly severe discoloration due to sunburn browning (Schrader et al., 2003). Different letters denote the probability having lower values in the scale (clean fruit); data were analyzed as ordinal categorical variables using the proportional odds model.

if reflective materials were deployed for the entire season.

Here, reflective fabrics increased reflected and diffuse $P A R$ in the middle of the row and within the canopy. Light is very important in apple production; it has been linked to increased fruit color (Meinhold et al., 2011), internal quality (Blanke, 2008), fruit number and size (Grout et al., 2004), and yield (Hanrahan et al., 2011). In our study, yield, fruit weight, and fruit number were unaffected because the reflective fabrics were installed near the end of the growing season. Red color development on apple fruit results from an accumulation of anthocyanin pigments, which has been demonstrated to be highly influenced by light intensity (Steyn et al., 2002; Vimolmangkang et al., 2014). Light quality also plays a crucial role in in anthocyanin biosynthesis in apple (Chen et al., 2021). Ultraviolet $\mathrm{B}$ and violet to blue light promote anthocyanin development (Mol et al., 1996; Steyn et al., 2002). Results from the current study showed reflective groundcover increased the light reflected in the ground in the violet to blue range. The increase in the amount of reflected light in the violet to blue range in our study from reflective groundcover explains the improvement in red skin color development in 'Honeycrisp' apple. Our results corroborate those reported by Weber et al. (2019) on 'Braeburn Mariri Red' apples were the use of reflective material under protective netting 7 weeks before harvest also improved red coloration. The deployment of reflective groundcover late in the growing season did not affect internal fruit quality because the reflective groundcovers were installed for only the fruit maturation phase (Lakso et al., 1999; Veberic et al., 2003). Similar results on internal fruit were reported by Meinhold et al. (2011) in 'Gala Mondial' apple, the use of film material and woven polyethylene fabric under protective netting 4 to 5 weeks before harvest did not affect fruit quality as measured by the Streif index. Conversely, Blanke (2008) reported increases in SSC where woven polyethylene fabric was used under protective netting for 'Jonagold' apple trees.

The benefits of using protective netting to reduce sunburn by reducing solar radiation are sometimes offset by reduced red color formation. The use of reflective groundcover under protective netting is an effective solution to more efficiently use solar radiation passed through protective netting to improve light conditions inside the tree canopy. Reflective groundcover reflect more light back into the tree canopy and can help mitigate potential fruit coloration issues sometimes associated with protective netting.

\section{Literature cited}

Blanke, M.M. 2008. Alternatives to reflective mulch cloth (Extenday ${ }^{\mathrm{TM}}$ ) for apple under hail net? Scientia Hort. 116(2):223-226, doi: 10.1016/j.scienta.2007.12.004.

Candian, V., M.G. Pansa, K. Santoro, D. Spadaro, L. Tavella, and R. Tedeschi. 2020. Photoselective exclusion netting in apple orchards: Effectiveness against pests and impact on beneficial arthropods, fungal diseases and fruit quality. Pest Manag. Sci. 76(1):179-187, doi: 10.1002/ps.5491.

Chen, Z., L. Yu, W. Liu, J. Zhang, N. Wang, and X. Chen. 2021. Research progress of fruit color development in apple (Malus domestica Borkh.). Plant Physiol. Biochem. 162:267-279, doi: 10.1016/j. plaphy.2021.02.033

Chouinard, G., J. Veilleux, F. Pelletier, M. Larose, V. Philion, V. Joubert, and D. Cormier. 2019. Impact of exclusion netting row covers on 'honeycrisp' apple trees grown under northeastern north american conditions: Effects on photosynthesis and fruit quality. Insects 10(7):214, doi: 10.3390/ insects10070214.

Corelli-Grappadelli, L.C. 2003. Light relations, p. 195-216. In: D.C. Ferree and I.J. Warrington (eds.). Apple: Botany, production and uses. CABI Publishing, Cambridge, MA.

Do Amarante, C.V.T., S.A. Steffens, and L.C. Argenta. 2011. Yield and fruit quality of 'Gala' and 'Fuji' apple trees protected by white anti-hail net. Scientia Hort. 129(1): 79-85, doi: 10.1016/j.scienta.2011.03. 010

Elkin, E. 2012. Beyond binary outcomes: Proc logistic to model ordinal and nominal dependent variables. 31 Mar. 2021. <https://support.sas.com/resources/ papers/proceedings12/427-2012.pdf $>$.

Felicetti, D.A. and L.E. Schrader. 2008. Photooxidative sunburn of apples: Characterization of a third type of apple sunburn. Intl. J. Fruit Sci. 8(3):160-172, doi: $10.1080 / 15538360802526472$.

Fouché, J.R., S.C. Roberts, S.J.E. Midgley, and W.J. Steyn. 2010. Peel color and blemishes in 'Granny Smith' apples in relation to canopy light environment. HortScience 
45(6):899-905, doi: 10.21273/HORT SCI.45.6.899.

Gindaba, J. and S.J.E. Wand. 2005. Comparative effects of evaporative cooling, kaolin particle film, and shade net on sunburn and fruit quality in apples. HortScience 40(3):592-596, doi: 10.21273/ HORTSCI.40.3.592.

Grout, B.W.W., C.V. Beale, and T.P.C. Johnson. 2004. The positive influence of year-round reflective mulch on apple yield and quality in commercial orchards. Acta Hort. 636:513-519, doi: 10.17660/ ActaHortic.2004.636.64.

Hanrahan, I., T.R. Schmidt, F. Castillo, and J.R. McFerson. 2011. Reflective ground covers increase yields of target fruit of apple and pear. Acta Hort. 903:1095-1100, doi: 10.17660/ActaHortic.2011.903.152.

Hanrahan, I. 2012. Starch iodine honeycrisp index. 15 Feb. 2021. <https://treefruit research.org//wp-content/uploads/2019/ 08/2012-Honeycrisp-Starch-Scale.pdf $>$.

Hirst, P.M., D.S. Tustin, and I.J. Warrington. 1990. Fruit colour responses of 'Granny Smith' apple to variable light environments. N. Z. J. Crop Hort. Sci. 18(4):205-214, doi: 10.1080/01140671. 1990.10428096 .

Iglesias, I. and S. Alegre. 2006. The effect of anti-hail nets on fruit protection, radiation, temperature, quality and profitability of ' $\mathrm{Mo}$ ndial Gala' apples. J. Appl. Hort. 8(2):91100, doi: 10.37855/jah.2006.v08i02.22.

Jackson, J.E. and R.O. Sharples. 1971. The influence of shade and within-tree position on apple fruit size, colour and storage quality. J. Hort. Sci. 46(3):277-287, doi: $10.1080 / 00221589.1971 .11514408$.

Kalcsits, L., S. Musacchi, D.R. Layne, T. Schmidt, G. Mupambi, S. Serra, M. Mendoza, and L. Asteggiano. 2017. Above and below-ground environmental changes associated with the use of photoselective protective netting to reduce sunburn in apple. Agr. For. Meteorol. 237-238:9-17, doi: 10.1016/j. agrformet.2017.01.016.

Lakso, A.N., J.N. Wunsche, J.W. Palmer, and L.C. Grappadelli. 1999. Measurement and modeling of carbon balance of the apple tree. HortScience 34(6):1040-1047, doi: 10.21273/HORTSCI.34.6.1040.

Lammertyn, J., M. Aerts, B.E. Verlinden, W. Schotsmans, and B.M. Nicolaï. 2000. Logistic regression analysis of factors influencing core breakdown in 'Conference' pears. Postharvest Biol. Technol. 20(1):25-37, doi: 10.1016/S0925-5214(00)00114-9.

Mditshwa, A., L.S. Magwaza, and S.Z. Tesfay. 2019. Shade netting on subtropical fruit: Effect on environmental conditions, tree physiology and fruit quality. Scientia Hort. 256:108556, doi: 10.1016/j. scienta.2019.108556.

Meinhold, T., L. Damerow, and M. Blanke. 2011. Reflective materials under hailnet improve orchard light utilisation, fruit quality and particularly fruit colouration. Scientia Hort. 127(3):447-451, doi: 10.1016/j.scienta.2010.09.006

Mol, J., G. Jenkins, E. Schafer, and D. Weiss. 1996. Signal perception, transduction, and gene expression involved in anthocyanin biosynthesis. Crit. Rev. Plant Sci. 15(5-6):525-557, doi: 10.1080/ 07352689609382369.

Mukherjee, A., S. Knoch, G. Chouinard, J.R. Tavares, and M.-J. Dumont. 2019. Use of bio-based polymers in agricultural exclusion nets: A perspective. Biosyst. Eng. 180:121-145, doi: 10.1016/j.bio systemseng.2019.01.017.

Mupambi, G., B.M. Anthony, D.R. Layne, S. Musacchi, S. Serra, T. Schmidt, and L.A. Kalcsits. 2018a. The influence of protective netting on tree physiology and fruit quality of apple: A review. Scientia Hort. 236:60-72, doi: 10.1016/j.scienta. 2018.03.014.

Mupambi, G., S. Musacchi, S. Serra, L.A. Kalcsits, D.R. Layne, and T. Schmidt. 2018b. Protective netting improves leaflevel photosynthetic light use efficiency in 'Honeycrisp' apple under heat stress. HortScience 53(10):1416-1422, doi: 10.21273/ HORTSCI13096-18.

Palmer, J.W. 1977. Light transmittance by apple leaves and canopies. J. Appl. Ecol. 14(2):505-513, doi: $10.2307 / 2402562$.

Racsko, J. and L.E. Schrader. 2012. Sunburn of apple fruit: Historical background, recent advances and future perspectives. Crit. Rev. Plant Sci. 31(6):455-504, doi: 10.1080/ 07352689.2012 .696453 .

Schmidt, T. 2010. Crop load and canopy management of apple. Final Project Report. Washington State Tree Fruit Research Commission Project \#571. 15 Feb. 2021. <https://treefruitresearch.org/report/ crop-load-and-canopy-management-ofapple- $2 />$.

Schrader, L.E., J. Zhang, and W.K. Duplanga. 2001. Two types of sunburn in apple caused by high fruit surface (peel) temperature. Plant Health Prog. 15 Mar. 2021. $<$ https://apsjournals.apsnet.org/doi/pdf/ 10.1094/PHP-2001-1004-01-RS $>$, doi: 10.1094/PHP-2001-1004-01-RS.

Schrader, L.E., J. Sun, D. Felicetti, J.-H. Seo, L. Jedlow, and J. Zhang. 2003. Stressinduced disorders: Effects on apple fruit quality. Proc. 30 Mar. 2021. <https:// www.researchgate.net/publication/27541
0344_Stress_induced_disorders_effect_on_ apple_fruit_quality\#: :text $=$ Heat $\% 20$ stress $\% 20$ on $\% 20$ fruit $\% 20$ can, $\% 2$ C $\% 202003$ b). $\% 20 \ldots>$.

Schwabe, W.W. and S.M. Lionakis. 1996. Leaf attitude in olive in relation to drought resistance. J. Hort. Sci. 71(1): 157-166, doi: 10.1080/14620316.1996. 11515392 .

Siegelman, H.W. and S.B. Hendricks. 1958. Photocontrol of anthocyanin synthesis in apple skin. Plant Physiol. 33(3): 185-190, doi: 10.1104/pp.33.3.185.

Solomakhin, A. and M. Blanke. 2010. Can coloured hailnets improve taste (sugar, sugar: Acid ratio), consumer appeal (colouration) and nutritional value (anthocyanin, vitamin C) of apple fruit? Lebensm. Wiss. Technol. 43(8):1277-1284, doi: 10.1016/ j.lwt.2010.02.020.

Solomakhin, A.A. and M.M. Blanke. 2007. Overcoming adverse effects of hailnets on fruit quality and microclimate in an apple orchard. J. Sci. Food Agr. 87(14):26252637, doi: 10.1002/jsfa.3022.

Steyn, W.J., S.J.E. Wand, D.M. Holcroft, and G. Jacobs. 2002. Anthocyanins in vegetative tissues: A proposed unified function in photoprotection. New Phytol. 155(3):349-361, doi: 10.1046/j.14698137.2002.00482.x.

Veberic, R., D. Vodnik, and F. Stampar. 2003. Carbon partitioning and seasonal dynamics of carbohydrates in the bark, leaves and fruits of apple (Malus domestica Borkh.) cv. Golden Delicious'. Eur. J. Hort. Sci. 68(5):222-226. https://www. pubhort.org/ejhs/2003/file_7875.pdf.

Vimolmangkang, S., D. Zheng, Y. Han, M.A. Khan, R.E. Soria-Guerra, and S.S. Korban. 2014. Transcriptome analysis of the exocarp of apple fruit identifies lightinduced genes involved in red color pigmentation. Gene 534(1):78-87, doi: 10.1016/ j.gene.2013.10.007.

Walter-Shea, E.A., J.M. Norman, B.L. Blad, and B.F. Robinson. 1991. Leaf reflectance and transmittance in soybean and corn. Agron. J. 83(3):631-636, doi: 10.2134/ agronj1991.00021962008300030026x.

Weber, S., L. Damerow, A. Kunz, and M. Blanke. 2019. Anthocyanin synthesis and light utilisation can be enhanced by reflective mulch-Visualisation of light penetration into a tree canopy. J. Plant Physiol. 233:52-57, doi: 10.1016/j.jplph.2018. 12.008 .

Wünsche, J.N., J. Bowen, I. Ferguson, A. Woolf, and T. McGhie. 2004. Sunburn on apples-Causes and control mechanisms. Acta Hort. 636:631-636, doi: 10.17660/ActaHortic.2004.636.78. 